\title{
15(R)-15-Methylprostaglandin $\mathrm{E}_{2}$ (Arbaprostil) の
}

\section{ラットにおける生体内動態の研究（第 5 報）： \\ 胎盤通過性, 乳汁中移行性および \\ 連続投与時の体内動態}

\author{
大澤 康次, 幡野恵, 西宮 一尋, 岡崎樹 \\ 中外製薬株式会社応用研究所 $=171$ 豊島区高田3-41-8 \\ 太田 真一, 宇田 文昭, 柳田 由紀, 檜垣 洋子, 吉田知江里 \\ 株式会社野村生物科学研究所 $\mathbf{T} 247$ 神奈川県鎌倉市梶原4-7-1
}

Key words : $15(\mathrm{R})-15$-methylprostaglandin $\mathrm{E}_{2}$, CU-83, Fetus, Milk, Repeated administration, Absorption, Distribution, Excretion, Rat

Studies on the metabolic fate of 15(R)-15-methylprostaglandin $\mathrm{E}_{2}$ (Arbaprostil)

in rats $(V)$ : Foeto-placental transfer and excretion into milk, and disposition after repeated administration

Yasutsugu Ohsawa, Megumi Hatano, Kazuhiro Nishimiya and Akira OKazaki

Applied Research Laboratories, Chugai Pharmaceutical Co., Ltd.

3-41-8 Takada, Toshima, Tokyo, 171, Japan

Shinichi Ohta, Fumiaki Uda, Yuki Yanagida, Yoko Higaki and Chieri Yoshida

NRI Life Science 4-7-1 Kajiwara, Kamakura, Kanagawa, 247, Japan

\section{Summary}

The distribution of radioactivity in the fetus and the excretion to the milk was studied following oral administration of ${ }^{3} \mathrm{H}-15(\mathrm{R})-15$-methylprostaglandin $\mathrm{E}_{2}\left({ }^{3} \mathrm{H}-\mathrm{CU}\right.$ 83) at a dose of $25 \mu \mathrm{g} / \mathrm{kg}$ to pregnant or lactating rats. The blood concentration, tissue accumulation and excretion of radioactivity were also examined during and after repeated oral administration of the compound at the same dose to male rats for 7 and 14 days.

After oral administration to pregnant rats, very low radioactivity was detected in the tissues of fetus on day 19 of gestation. The blood level of radioactivity in the fetus was also lower than the maternal blood level and its ratio was about 0.08 times at $6 \mathrm{hr}$ after administration.

The radioactivity in milk reached the maximum level $2 \mathrm{hr}$ after oral administration to lactating rats but was $0.23-0.72$ times in comparison to that in the maternal blood level.

The maximum blood concentration ( $\mathrm{Cmax}$ ) and the area under the blood concentration-time curve (AUC) for 24 hour period after single and final dosing of the 7 th and 14 th repeated administration were $3.17 \mathrm{ng}$ eq. $/ \mathrm{m} l$ and $40.03 \mathrm{ng}$ eq. $\mathrm{hr} / \mathrm{m} l, 3.41 \mathrm{ng}$ eq. $/ \mathrm{m} l$ and $45.69 \mathrm{ng}$ eq. $\cdot \mathrm{hr} / \mathrm{m} l$ and $2.97 \mathrm{ng}$ eq. $/ \mathrm{m} l$ and $46.91 \mathrm{ng}$ eq. $\mathrm{hr} / \mathrm{m} l$, respectively. The concentrations of radioactivity in the plasma, blood and tissues after 7 th repeated administration of ${ }^{3} \mathrm{H}-\mathrm{CU}-83$ were slightly higher than those after the single administration. The concentrations in the tissues after 14 th repeated administrations were similar to those after the 7 th repeated.

Excretion of radioactivity in urine and feces was almost constant during 14 th repeated administration and was almost completed within $24 \mathrm{hr}$ after the final administration. 


\section{緒 言}

15(R)-15-Methylprostaglandin $\mathrm{E}_{2}$ (Arbaprostil:CU-83) は, 消化性潰瘍の治療薬として開発 中の化合物である. 本化合物は経口投与時に胃内 酸性下, ラセミ化を受け, そのエピマー体 15(S)15-methylprostaglandin $\mathrm{E}_{2}$ (CU-83(S)) を生じ る. 両化合物共に活性を有する ${ }^{12}$ ため, 著者らは ${ }^{3} \mathrm{H}-\mathrm{CU}-83$ 抢よび ${ }^{3} \mathrm{H}-\mathrm{CU}-83(\mathrm{~S})$ を用い, これら の体内動態を比較検討 ${ }^{2,3,4)}$ した.

今回は， ${ }^{3} \mathrm{H}$ 標識した CU-83 を用い,さらに 胎盤通過性, 乳汁中移行性および単回投与を対照 に, 連続投与時の体内動態について検討したので 報告する.

\section{実験材料および方法}

\section{1. 被験化合物および試薬}

${ }^{3} \mathrm{H}$ 標識した CU-83 (比放射能 $2.74 \mathrm{mCi} / \mathrm{mg}$ ) および非標識の CU-83 は, Upjohn 社より入手 したものを使用した（Fig. 1). 高速液体クロマ トグラフィーによる放射化学的純度は，95.0\%以 上であった．投与に用いた媒体や実験に用いた溶 媒および試薬類は, 日本薬局方規格あるいは市販 の特級品を用いた。

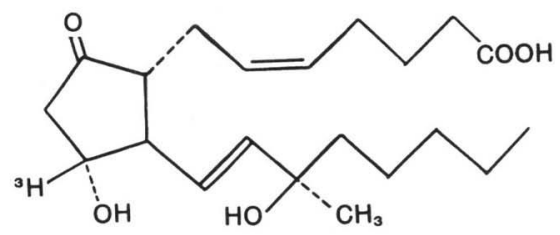

Fig. 1. Chemical structure of radiolabelled CU-83

\section{2. 使用動物}

Sprague-Dawley 系ラット（Slc:SD）を静岡 県実験動物農業協同組合より購入した. 胎盤通過 性の検討には10〜12週齢の妊娠ラットを購入し， 予備飼育後, 妊娠19日目で実験に供した。乳汁中 移行の検討には, 同様に購入した妊娠動物を飼育 し, 分婏後14日目で実験に供した. 連続投与実験 では雄ラットを購入し, 予備飼育後, $7 \sim 8$ 週龄 で実験に供した。飼育は, 温度 $23 \pm 2{ }^{\circ} \mathrm{C}$, 湿度 35 〜 $75 \%$, 明暗サイクル12時間に調節された飼育室 内で行った. 飼料 CRF-1（オリェンタル酵母工
業）特よび水道水は自由に摂取させた.

\section{3. 投与液の調製および投与}

${ }^{3} \mathrm{H}-\mathrm{CU}-83$ を非標識 CU-83 で希釈した後, 最 終濃度が $5 \%$ に相当するエタノールを加えて溶解 し, 注射用蒸留水を加えて希釈, 調製した. 投与 量は $25 \mu \mathrm{g} /$ 約 $50 \mu \mathrm{Ci} / 5 \mathrm{ml} / \mathrm{kg}$ とした. 胎盤通過 性および乳汁中移行性の検討時は 16 時間以上絶食 した動物に, また連続投与の検討時は, 絶食して いない動物にゾンデを用いて経口投与した。

\section{4. 動物実験および試料の採取 \\ 1) 胎盤通過性実験}

妊娠19日目の雌ラット9 9 匹を 3 匹ずつ 3 群に分 け，それぞれ ${ }^{3} \mathrm{H}-\mathrm{CU}-83$ を経口投与した後 2,6 および24時間にェーテル麻酔下, 腹大動脈より採 血致死させ, 母獣並びに胎仔の各組織を採取し た。

採取した組織は, 母獣からは血液, 血漿, 心, 肺, 肝, 腎, 卵巣, 子宮, 胎盤, 羊水, また胎仔 からは血液, 脳, 心, 肺, 肝, 腎および胎仔全体 とした.

\section{2）乳汁中移行性実験}

分娩後14日目の雌ラット5 匹に ${ }^{3} \mathrm{H}-\mathrm{CU}-83$ を 経口投与した後 30 分, 2,6 打よび 24 時間に乳汁 と尾静脈血を採取した.な拈, ${ }^{3} \mathrm{H}-\mathrm{CU}-83$ 投与直 後, または乳汁採取前 1 時間にオキシトシンを腹 腔内に投与した。

\section{3）連続投与時の体内動態実験}

雄ラット9 匹を 3 匹ずつ 3 群に分け，それぞれ ${ }^{3} \mathrm{H}-\mathrm{CU}-83$ を 1 日 1 回の割合で, 単回投与を対照 にし， 7 日間および 14 日間連続経口投与した，各 群の最終投与後 $15,30,45$ 分, $1,2,3,4,6$, 8 および24時間に尾静脈より血液を採取した。 た, 最終投与後 24 時間にェーテル麻酔下, 腹大動 脈より採血致死せしめ各組織を採取した. 別の雄 ラット 3 匹に ${ }^{3} \mathrm{H}-\mathrm{CU}-83$ を 1 日 1 回 14 日間経口 投与し, 毎回投与後 24 時間および最終投与後は 168 時間まで24時間毎に血液を採取し, また,最終投与 後168時間に動物を致死せしめ組織を採取した。

なお, 採取した組織は, 血液, 血漿, 脳, 下垂 体, 心, 肺, 脾, 膵, 腎, 副腎, 胃, 小腸, 盲腸, 大腸, 胃内容物, 腸内容物, 腸間膜リンパ節, 眼 球, 胸腺, 顎下腺, 甲状腺, 白色脂肪 (精巣上体 周辺部), 褐色脂肪, 筋肉, 皮膚; 膀脱, 精巣上 
体, 精囊, 前立腺, 骨髄, 骨䯣採取後の骨および 組織採取後の屍体とした.

また, 別の雄ラット 4 匹に 1 日 1 回 14 日間 ${ }^{3} \mathrm{H}-$ CU-83 を経口投与し, 最終投与後168時間まで 24 時間毎に尿扣よび粪を採取した。

\section{5. 試料の前処理および放射能の測定}

血液, 血漿, 羊水は $50 \sim 100 \mu l$ を脱脂綿 $(1 \times$ $1 \times 0.5 \mathrm{~cm})$ を入れたコンバストコーン (Packard 社）に取り，減圧乾燥後サンプルオキシダイザー Model 306 B (Packard 社) で燃焼し, 測定用試 料とした. 尿は $100 \mu l$ ずつ 2 本のバイアルに取 り, 一方は直接, もう一方は減圧乾燥後, $100 \mu l$ の蒸留水を加兄て溶解後, シンチレーター Insta Gel (Packard 社) を加えて測定用試料とした.

乳汁は $50 \mu l$ 前後をバイアルにとり，直接シンチ レーターを加えて測定用試料にした。翼は重量を 測定後, 同量の蒸留水を加えてホモジナイズした 後, $50 \sim 100 \mathrm{mg}$ をコンバストコーンに取り，乾 燥前拉よび減圧乾燥後にサンプルオキシダイザー により燃焼し，測定用試料とした，組織は，小さ いものは全量を, それ以外は八サミによる細切 後, あるいは蒸留水を加学てホモジナイズした 後, 組織実質量として約 $50 \mathrm{mg}$ をコンバストコ ーンにとり，サンプルオキシダイザーにより燃焼 し測定用試料とした.サンプルオキシダイザーに よる燃焼時の回収率は, 標準試料を用いて補正し た。

放射能の測定は, 液体シンチレーションカウン ター Tri-Carb 460CD あるいは4640 (Packard 社）を使用し行った. 計数効率, クェンチングな ぞの補正は, 外部標準線源法により行った。 また， 試料の放射能よりバックグランド值を差し引いた 值が $20 \mathrm{dpm}$ のレベルを測定限界とした.

\section{6. デー夕処理および解析}

各測定值は特記しない限り, 平均と標準誤差 （S.E）で示した. 血液中濃度推移の解析は, 各群 の平均血液中濃度推移で行った. 血液中濃度一時 間曲線下面積 (AUC) は, 平均血液中濃度推移か ら台形法により求めた。

\section{実験結果}

\section{1. 胎盤通過性}

妊娠19日目の雌ラットに ${ }^{3} \mathrm{H}-\mathrm{CU}-83$ を経口投
与し, 母獣および胎仔の組織内放射能濃度を測定 した結果は Table I に示した. 母獣の組織内濃 度で高い值を示したのは肝蔵と腎臓であった。こ れらの濃度は投与後 2 時間が最も高く, それぞれ 血漿中放射能濃度の約 2.4 倍と約 1.9 倍の值を示し た後, 経時的に消失した. その他の組織内濃度 は, 投与後 2 時間から 6 時間にかけわずかに上昇 し，投与後 6 時間にその最高濃度を示したが，い ずれも血漿中濃度より低い值であり, 羊水を除き 投与後 24 時間には減少した. 羊水中の放射能濃度 は, 投与後 24 時間まで徐々に増加したが，その濃 度は非常に低かった。

胎仔の組織内放射能濃度も, 投与後 6 時間に最 高值を示したが, いずれも母獣の組織内濃度と比 べると極めて低かった。また，胎仔の血液中放射 能濃度も母獣に比べて低く, その最高濃度を示し た投与後 6 時間でも母獣血液の約 0.08 倍であっ た.この胎仔血液中濃度よりも高い濃度を示した 胎仔組織は肝臓だけであり, しかもとの濃度は胎 仔血液中濃度の約1.3〜1.6倍の低值であった．胎 仔肺および胎仔腎蔵の濃度は, 胎仔血液とほぼ同 じであった。

\section{2. 乳汁中移行性}

分娩後14日目の授乳期の雌ラットに ${ }^{3} \mathrm{H}-\mathrm{CU}-83$ を経口投与し, 血液中および乳汁中放射能濃度を 測定した結果とその比を Fig. 2 に示した。血液 中濃度は投与後30分に $5.86 \mathrm{ng}$ eq./m $l$ の最高值 を示した後, 半減期約 9 時間で経時的に消失した. 一方, 乳汁中濃度は投与後 2 時間に $2.10 \mathrm{ng}$ eq./ $\mathrm{m} l$ を示し, それ以後は血液にほぼ平行し消失し た. 乳汁中濃度の血液中濃度に対する比率は, 投 与後 30 分の 0.23 から投与後 24 時間の 0.72 へと時間 と共に上昇したが, 乳汁中濃度はいずれの時間に 扔いても血液中濃度より低い值であった。

\section{3. 連続投与時の体内動態}

雄ラットに ${ }^{3} \mathrm{H}-\mathrm{CU}-83$ を 1 日 1 回の割合で, 単回投与および 7 日間と 14 日間連続経口投与し, 最終投与後 24 時間までの血液中放射能濃度の推移 と 14 日間連続投与後 168 時間までの投与開始から 24時間毎の血液中濃度を Fig. 3 に示した.いずれ の投与回数の場合にも, 最高血液中濃度 (Cmax) には最終投与後 2 または 3 時間に達し, $\mathrm{Cmax}$ (単 回投与では $3.17 \mathrm{ng} \mathrm{eq.} / \mathrm{ml}, 7$ 日間投与では 3.41 
Table I. Tissue concentrations of radioactivity after oral administration of ${ }^{3} \mathrm{H}-\mathrm{CU}-83$ to pregnant rats

\begin{tabular}{|c|c|c|c|}
\hline \multirow{2}{*}{ Tissue } & \multicolumn{3}{|c|}{ Concentration (ng eq. of $\mathrm{CU}-83 / \mathrm{ml}$ or $\mathrm{g}$ ) } \\
\hline & $2 \mathrm{hr}$ & $6 \mathrm{hr}$ & $24 \mathrm{hr}$ \\
\hline Blood & $10.83 \pm 2.02(0.72)$ & $10.59 \pm 1.05(0.69)$ & $0.79 \pm 0.05(0.71)$ \\
\hline Plasma & $14.99 \pm 2.56(1.00)$ & $15.46 \pm 1.49(1.00)$ & $1.13 \pm 0.08(1.00)$ \\
\hline Heart & $2.66 \pm 0.40(0.18)$ & $3.09 \pm 0.39(0.20)$ & $0.53 \pm 0.05(0.47)$ \\
\hline Lung & $4.55 \pm 0.65(0.30)$ & $4.87 \pm 0.51(0.31)$ & $0.58 \pm 0.07(0.51)$ \\
\hline Liver & $36.41 \pm 4.07(2.43)$ & $26.06 \pm 0.35(1.69)$ & $2.00 \pm 0.05(1.78)$ \\
\hline Kidney & $27.94 \pm 4.25(1.86)$ & $18.73 \pm 0.57(1.21)$ & $2.45 \pm 0.02(2.17)$ \\
\hline Uterus & $4.97 \pm 0.80(0.33)$ & $5.43 \pm 0.38(0.35)$ & $1.28 \pm 0.08(1.13)$ \\
\hline Ovary & $3.46 \pm 0.77(0.23)$ & $3.62 \pm 0.43(0.23)$ & $0.42 \pm 0.04(0.38)$ \\
\hline Placenta & $2.95 \pm 0.39(0.20)$ & $3.76 \pm 0.57(0.24)$ & $0.96 \pm 0.08(0.85)$ \\
\hline Amniotic fluid & $0.18 \pm 0.03(0.01)$ & $0.29 \pm 0.06(0.02)$ & $0.58 \pm 0.02(0.52)$ \\
\hline Fetus & $0.61 \pm 0.14(0.04)$ & $0.79 \pm 0.13(0.05)$ & $0.45 \pm 0.03(0.40)$ \\
\hline Fetal blood & $0.69 \pm 0.13(0.05)$ & $0.90 \pm 0.10(0.06)$ & $0.36 \pm 0.02(0.32)$ \\
\hline Fetal brain & $0.17 \pm 0.04(0.01)$ & $0.22 \pm 0.04(0.01)$ & $0.10 \pm 0.01(0.09)$ \\
\hline Fetal heart & $0.40 \pm 0.10(0.03)$ & $0.51 \pm 0.06(0.03)$ & $0.31 \pm 0.02(0.27)$ \\
\hline Fetal lung & $0.74 \pm 0.22(0.05)$ & $0.86 \pm 0.23(0.06)$ & $0.37 \pm 0.03(0.33)$ \\
\hline Fetal liver & $0.91 \pm 0.24(0.06)$ & $1.27 \pm 0.15(0.08)$ & $0.56 \pm 0.04(0.50)$ \\
\hline Fetal kidney & $0.58 \pm 0.10(0.04)$ & $0.97 \pm 0.12(0.06)$ & $0.85 \pm 0.08(0.75)$ \\
\hline Carcass & $10.89 \pm 0.83(0.73)$ & $9.69 \pm 0.21(0.63)$ & $0.94 \pm 0.04(0.83)$ \\
\hline
\end{tabular}

Pregnant rats were given ${ }^{3} \mathrm{H}-\mathrm{CU}-83$ at a dose of $25 \mu \mathrm{g} / \mathrm{kg}$ on day 19 of gestation.

Each value was expressed as the mean \pm S.E. of three animals.

Values in the parentheses were the tissue-to-plasma concentration ratios.

Concentrations in fetuses and fetal tissues were determined in pooled tissues from 3 fetuses.

The number of the fetuses in a pregnant rats varied from 12 to 15 .

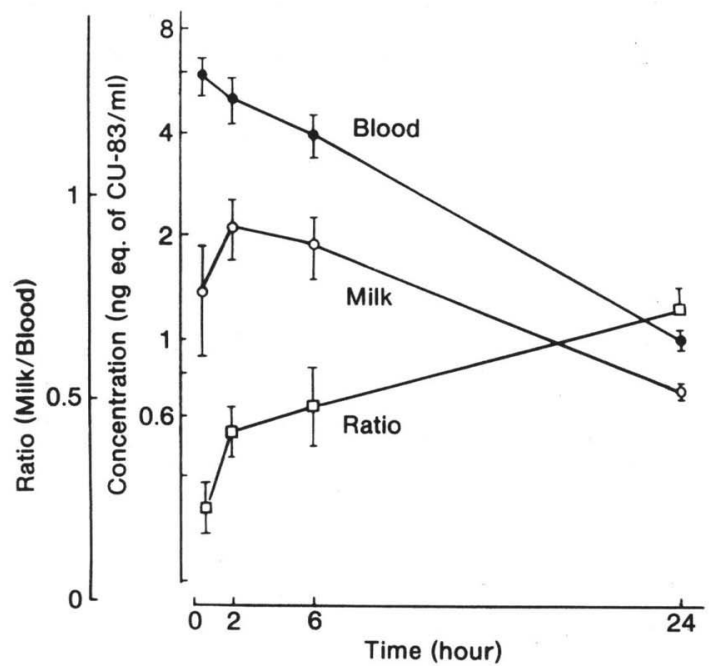

Fig. 2. Levels of radioactivity in blood and milk and milk-to-blood concentration ratios after oral administration of ${ }^{3} \mathrm{H}-\mathrm{CU}-83$ to lactating rats

Each point with vertical bar represent the mean \pm S.E. of five animals. $\mathrm{ng}$ eq./ml, 14日間投与では $2.97 \mathrm{ng} \mathrm{eq./ml)} \mathrm{は,}$ 7 日間投与で増加の傾向はみられたが有意な差で はなかった。また，最終投与後24時間までの AUC は，単回投与では $40.03 \mathrm{ng} \mathrm{eq} \cdot \cdot \mathrm{hr} / \mathrm{ml}, 7$ 日間投 与では $45.69 \mathrm{ng} \mathrm{eq} \cdot \cdot \mathrm{hr} / \mathrm{ml}, 14$ 日間投与では $46.91 \mathrm{ng}$ eq. $\cdot \mathrm{hr} / \mathrm{m} l$ で, $\mathrm{Cmax}$ と同様に 7 日間 投与では増加の傾向がみられたが，有意な差では なかった．投与期間中の 24 時間毎の血液 中濃 度 は, 投与開始 5 日までは上昇し, その後ほぼ一定 （およそ $0.4 〜 0.6 \mathrm{ng} \mathrm{eq.} / \mathrm{ml}$ ) となる傾向を示し たが，上昇の程度は小さなものであった。連続投 与後の168時間には極めて低い濃度となった。

雄ラットに ${ }^{3} \mathrm{H}-\mathrm{CU}-83$ を単回と 1 日 1 回で 7 日間および14日間連続投与後24時間および14日間 投与後168時間の組織内濃度を Table II に示し た. 大部分の組織に特いて, 単回投与から 7 日間 投与へ濃度の上昇が見られたが，7 日間投与と 14 日間投与ではほぼ同じ濃度を示した。単回投与の 


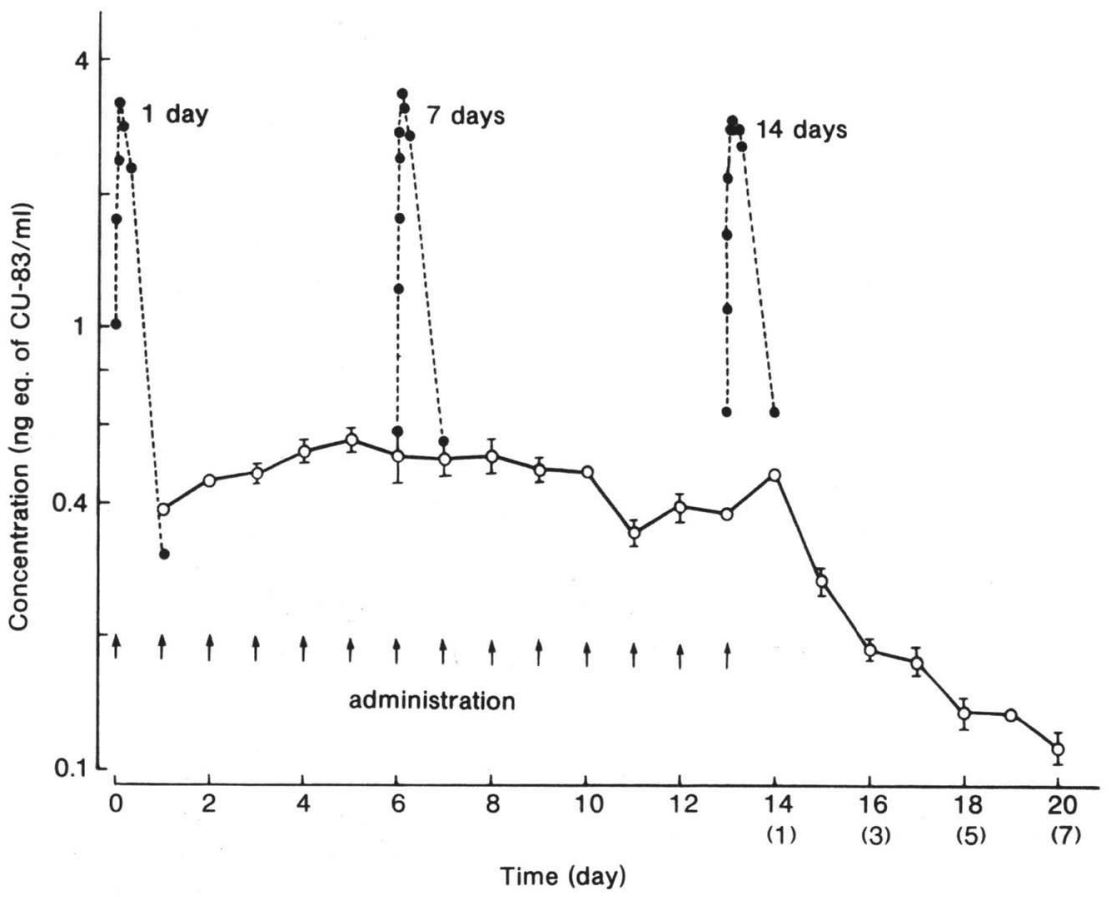

Fig. 3. Blood concentrations of radioactivity after single and consecutive oral administration of ${ }^{3} \mathrm{H}-\mathrm{CU}-83$ for 7 or 14 days at a daily dose of 25 $\mu \mathrm{g} / \mathrm{kg}$ to male rats

Concentration of radioactivity at $24 \mathrm{hr}$ was determined after each administration (O) and at $15,30,45 \mathrm{~min}, 1,2,3,4,6,8$ and $24 \mathrm{hr}$ after single, 7 th or 14 th administration (C).

The numbers in parentheses show a time (day) after the last administration for 14 days.

Each point with vertical bar represents the mean \pm S.E. of three animals.

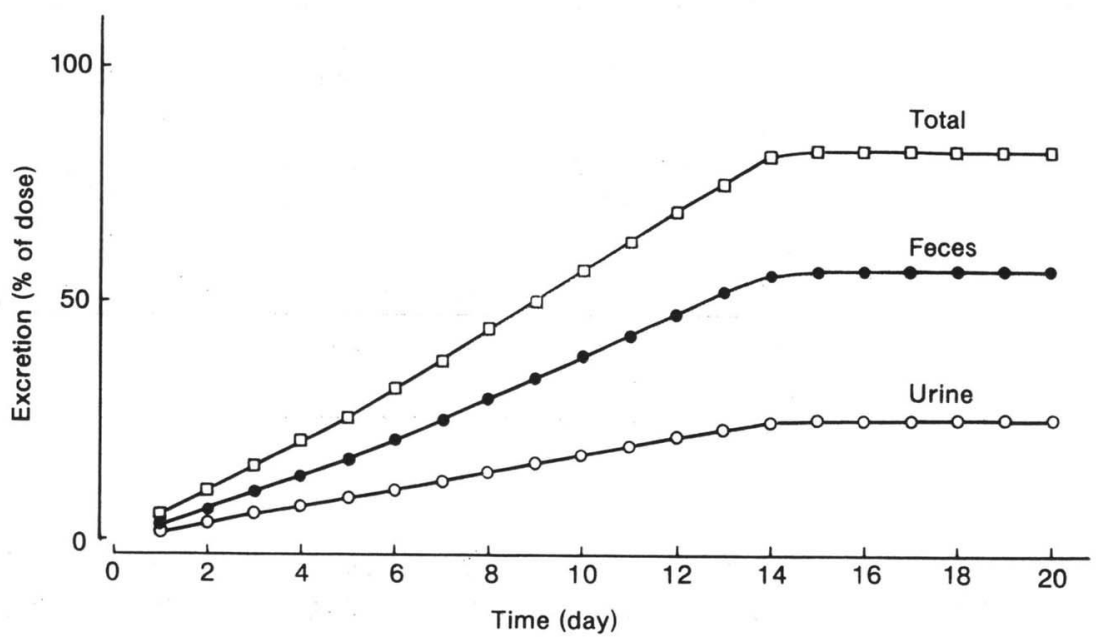

Fig. 4. Cumulative excretion of radioactivity during and after consecutive oral administration of ${ }^{3} \mathrm{H}-\mathrm{CU}-83$ to male rats

Each point represents the mean of four animals. 
Tabe II. Tissue concentrations of radioactivity after consecutive oral administration of ${ }^{3} \mathrm{H}-\mathrm{CU}-83$ to male rats

\begin{tabular}{|c|c|c|c|c|}
\hline \multirow{2}{*}{ Tissue } & \multicolumn{4}{|c|}{ Concentration (ng eq. of $\mathrm{CU}-83 / \mathrm{ml}$ or $\mathrm{g}$ ) } \\
\hline & 1 day & 7 days & 14 days & $168 \mathrm{hr}$ after 14 days \\
\hline Bood & $0.33 \pm 0.03(0.88)$ & $0.51 \pm 0.02(0.87)$ & $0.68 \pm 0.05(0.76)$ & $0.15 \pm 0.00(1.45)$ \\
\hline Plasma & $0.38 \pm 0.03(1.00)$ & $0.58 \pm 0.01(1.00)$ & $0.90 \pm 0.05(1.00)$ & $0.10 \pm 0.00(1.00)$ \\
\hline Brain & $0.11 \pm 0.01(0.30)$ & $0.30 \pm 0.02(0.52)$ & $0.30 \pm 0.02(0.33)$ & $0.18 \pm 0.01(1.73)$ \\
\hline Pituitary gl. & $0.94 \pm 0.18 \quad(2.49)$ & $1.88 \pm 0.18(3.24)$ & $1.30 \pm 0.09(1.45)$ & $\mathrm{n} . \mathrm{d}$ \\
\hline Eye ball & $0.06 \pm 0.00(0.15)$ & $0.14 \pm 0.01(0.23)$ & $0.13 \pm 0.01(0.14)$ & $0.05 \pm 0.01(0.44)$ \\
\hline Submaxillary gl. & $0.22 \pm 0.00(0.58)$ & $0.51 \pm 0.01(0.88)$ & $0.36 \pm 0.02(0.40)$ & $0.18 \pm 0.01(1.79)$ \\
\hline Thyroid gl. & $0.57 \pm 0.06(1.52)$ & $2.09 \pm 0.60(3.62)$ & $0.99 \pm 0.11(1.10)$ & $\mathrm{n} \cdot \mathrm{d}$. \\
\hline Thymus & $0.19 \pm 0.00(0.51)$ & $0.47 \pm 0.02(0.81)$ & $0.33 \pm 0.01(0.37)$ & $0.17 \pm 0.01(1.65)$ \\
\hline Heart & $0.22 \pm 0.00(0.58)$ & $0.38 \pm 0.02(0.65)$ & $0.41 \pm 0.01(0.46)$ & $0.18 \pm 0.02(1.77)$ \\
\hline Lung & $0.21 \pm 0.01(0.55)$ & $0.41 \pm 0.01(0.71)$ & $0.44 \pm 0.04(0.48)$ & $0.15 \pm 0.01(1.44)$ \\
\hline Liver & $1.52 \pm 0.29(4.02)$ & $2.05 \pm 0.39(3.54)$ & $2.69 \pm 0.24(2.99)$ & $0.35 \pm 0.03(3.40)$ \\
\hline Spleen & $0.18 \pm 0.01(0.47)$ & $0.48 \pm 0.01(0.84)$ & $0.31 \pm 0.01(0.34)$ & $0.17 \pm 0.01(1.70)$ \\
\hline Pancreas & $0.23 \pm 0.02(0.60)$ & $0.47 \pm 0.03(0.81)$ & $0.36 \pm 0.07(0.40)$ & $0.19 \pm 0.01(1.85)$ \\
\hline Kidney & $0.50 \pm 0.05(1.33)$ & $0.90 \pm 0.06(1.55)$ & $1.16 \pm 0.10(1.30)$ & $0.28 \pm 0.01 \quad(2.71)$ \\
\hline Adrenal & $0.26 \pm 0.01(0.68)$ & $0.63 \pm 0.04(1.08)$ & $0.40 \pm 0.03(0.45)$ & $0.12 \pm 0.00(1.19)$ \\
\hline Testis & $0.17 \pm 0.01(0.45)$ & $0.27 \pm 0.01(0.47)$ & $0.29 \pm 0.02(0.33)$ & $0.15 \pm 0.01(1.44)$ \\
\hline Epididymis & $0.21 \pm 0.00(0.55)$ & $0.39 \pm 0.02(0.67)$ & $0.26 \pm 0.02(0.29)$ & $0.16 \pm 0.02(1.59)$ \\
\hline Prostate gl. & $0.12 \pm 0.00(0.30)$ & $0.24 \pm 0.01(0.42)$ & $0.22 \pm 0.01(0.25)$ & $0.06 \pm 0.00(0.63)$ \\
\hline M-lymph nodes & $0.16 \pm 0.03(0.42)$ & $0.37 \pm 0.00(0.64)$ & $0.31 \pm 0.02(0.34)$ & $0.11 \pm 0.00(1.07)$ \\
\hline Skeletal muscle & $0.15 \pm 0.04(0.39)$ & $0.26 \pm 0.00(0.45)$ & $0.17 \pm 0.01(0.19)$ & $0.16 \pm 0.00(1.59)$ \\
\hline Skin & $0.19 \pm 0.01(0.49)$ & $0.44 \pm 0.01(0.76)$ & $0.29 \pm 0.03(0.32)$ & $0.19 \pm 0.01(1.87)$ \\
\hline Bone & $0.09 \pm 0.01(0.23)$ & $0.13 \pm 0.01(0.23)$ & $0.17 \pm 0.01(0.19)$ & $0.09 \pm 0.01(0.88)$ \\
\hline Bone marrow & $0.31 \pm 0.07(0.82)$ & $0.61 \pm 0.11(1.05)$ & $0.39 \pm 0.02(0.43)$ & $0.12 \pm 0.00(1.19)$ \\
\hline Urinary bladder & $0.38 \pm 0.06(1.01)$ & $0.56 \pm 0.04(0.97)$ & $0.34 \pm 0.05(0.38)$ & $0.14 \pm 0.01(1.36)$ \\
\hline Stomach & $2.78 \pm 0.45(7.35)$ & $9.22 \pm 4.93(15.92)$ & $7.06 \pm 0.39(7.85)$ & $0.23 \pm 0.01(2.22)$ \\
\hline Small intestine & $0.96 \pm 0.26(2.55)$ & $0.88 \pm 0.23(1.53)$ & $0.97 \pm 0.05(1.08)$ & $0.15 \pm 0.01(1.48)$ \\
\hline Large intestine & $4.27 \pm 1.16(11.28)$ & $2.97 \pm 1.18(5.13)$ & $4.78 \pm 1.04(5.32)$ & $0.14 \pm 0.01(1.36)$ \\
\hline Cecum & $4.50 \pm 1.14$ & $3.74 \pm 1.13(6.45)$ & $6.30 \pm 1.06(7.01)$ & $0.14 \pm 0.01(1.39)$ \\
\hline Gastric contents & $0.33 \pm 0.09(0.87)$ & $0.56 \pm 0.16(0.97)$ & $0.72 \pm 0.31(0.80)$ & $0.05 \pm 0.00(0.51)$ \\
\hline Epididymal fat & $0.12 \pm 0.00(0.31)$ & $0.23 \pm 0.02(0.40)$ & $0.14 \pm 0.01(0.15)$ & $0.18 \pm 0.01(1.75)$ \\
\hline Brown fat & $0.18 \pm 0.01(0.48)$ & $0.40 \pm 0.01(0.69)$ & $0.40 \pm 0.04(0.44)$ & $0.21 \pm 0.00(2.01)$ \\
\hline Seminal vesicle & $0.13 \pm 0.01(0.34)$ & $0.30 \pm 0.02(0.52)$ & $0.24 \pm 0.01(0.26)$ & $0.11 \pm 0.00(1.03)$ \\
\hline Intestinal contents & $18.42 \pm 4.12(48.69)$ & $13.93 \pm 4.36(24.06)$ & $23.21 \pm 0.78(25.82)$ & $0.07 \pm 0.00(0.68)$ \\
\hline Carcass & $0.13 \pm 0.02(0.36)$ & $0.54 \pm 0.09(0.93)$ & $0.77 \pm 0.14(0.86)$ & $0.19 \pm 0.01(1.88)$ \\
\hline
\end{tabular}

Rats were given ${ }^{3} \mathrm{H}-\mathrm{CU}-83$ at daily dose of $25 \mu \mathrm{g} / \mathrm{kg}$ for 1,7 or 14 days.

Each value was expressed as the mean \pm S.E. of three animals.

Values in the parentheses present the tissue-to-plasma concentration ratios.

n.d. : not detected $(<20 \mathrm{dpm} /$ sample $)$.

場合，消化管およびその内容物を除き最も高い濃 度を示した組織は肝臓で, その濃度は血漿中濃度 の約 4 倍であった. 次いで, 下垂体, 甲状腺, 腎臓 の順に高い濃度を示し，その他の組織では血漿よ り低い濃度であった。 7 日間および14日間投与の
場合も, 濃度の順位に違いはあるものの, 単回投 与の場合と同様に肝臓, 腎臓, 下垂体, 甲状腺に おいて，血漿より高い濃度を示したが，最も高い 組織の濃度でも血漿の 4 倍以下であった，また， その他の組織に拈いても単回投与の場合と同様の 
傾向を示した．14日間投与後の 168 時間の組織内 濃度は, すべての組織について14日間投与後の 24 時間と比べ低下しており, さらに単回投与後 24 時 間值と比較しても同程度以下に低下した。

雄ラットに ${ }^{3} \mathrm{H}-\mathrm{CU}-83$ を 1 日 1 回 14 日間連続 投与し, 最終投与後 168 時間までの 24 時間毎の尿, 粪中への排泄量を全投与量に対する累積排泄率と して Fig. 4 に示した. 尿, 粪中への排泄率は投 与期間中はほぼ直線的に増加し, 最終投与後 24 時 間以後はほとんど増加せず，排泄は最終投与後 24 時間でほぼ終了した．最終投与後 168 時間までに 全投与量の尿中には $25.23 \%$, 糞中には $56.87 \%$ が 排泄された。

\section{考察}

本化合物の体内動態に関しては, 組織分布 ${ }^{5)} の$ 一部と代謝 ${ }^{6)}$ が検討されている。また，著者らは すでに ${ }^{3} \mathrm{H}$ で標識した CU-83 を用いてラットに 护ける血液中濃度の推移, 尿粪中排泄, 腸肝循環, 蛋白結合抢よび代謝物について報告 ${ }^{2,3}$ したが，

本研究ではさらに胎盤通過性, 乳汁中移行性㧍よ び連続投与時の体内動態について検討した.

妊娠19日目のラットに ${ }^{3} \mathrm{H}-\mathrm{CU}-83$ 経口投与し た後の胎仔組織中の放射能濃度は母獣に比べ極め て低いことから，CU-83 抢よびその代謝物は胎 盤を極めて通過しにくいことが明らかとなった。 母獣で高い濃度を示した組織は肝蔵と腎臓であっ たが，その濃度は血液中濃度の数倍程度であっ た.

授乳期のラットに ${ }^{3} \mathrm{H}-\mathrm{CU}-83$ を経口投与した 後の乳汁中濃度は血液に比べて低く, 乳汁中への 移行性は小さいと考光られた。 CU-83 は生体内 に吸収された後, 速やかに代謝を受けるが，これ らの代謝物はいずれも酸性化合物であり, 乳汁中 への移行性が塩基性化合物では大きく, 酸性化合 物では小さいでとされていることと一致した.

${ }^{3} \mathrm{H}-\mathrm{CU}-83$ を 1 日 1 回の割合で連続経口投与す ると, 各投与後 24 時間の血液中濃度は, 投与開始 後 5 日まで上昇し, その後一定となる傾向を示し たが，上昇の程度は小さかった， 7 日間执よび 14 日間投与の最終投与後の最高血液中濃度および 24 時間までの AUCについては, 単回投与の結果と 有意差はなかった。 また，単回投与と 7 日間およ
び14日間投与後 24 時間の組織内濃度については, 単回投与に比べ 7 日間投与で上昇が見られたが, 7 日間投与と 14 日間投与では浪涪同じ濃度を示し た、したがって，1日 1 回の連続経口投与により 定常状態に達するためには特よそ5 日を要する が，定常状態に打けるレベルは単回投与に比べや や高い程度であると考学られる. 各投与後 24 時間 の組織内濃度で高い值を示したのは, 消化管組織 であり, 次いで肝蔵であった。しかし, これら組 織の分布量は非常に低かった.

尿, 粪中への放射能の排泄は投与期間中は比例 的に増加したが, 最終投与後 24 時間までにほぼ終 了した。 また， 14 日投与後 168 時間の組織内濃度 は, 単回投与後 24 時間と同程度あるいはそれ以下 に低下した. 以上のことから，CU-83 の生体へ の蓄積性は極めて低く, 投与終了とともに速やか に排泄され体内に残留しないと考光られる。

\section{要 約}

妊娠ラットと授乳中の母獣に ${ }^{3} \mathrm{H}-\mathrm{CU}-83$ を 25 $\mu \mathrm{g} / \mathrm{kg}$ 経口投与し, 胎盤通過性および乳汁中への 移行性を検討した。 また, 雄ラットに ${ }^{3} \mathrm{H}-\mathrm{CU}-83$ を $25 \mu \mathrm{g} / \mathrm{kg}$ で 1 日 1 回で 7 日間めるいは 14 日間 連続経口投与した際の体内動態を単回投与の結果 と比較検討した.

妊娠19日の雌ラットに経口投与した時の母獣の 組織内放射能濃度で高い值を示したのは肝臓と腎 臓であったが，それぞれ血漿中濃度の約 2.4 倍と 約 1.9 倍であった. 胎仔の組織内濃度は投与後 6 時間に最高值を示したが，いずれも母獣に比べ極 めて低い值であり，CU-83 およびその代謝物は 胎盤を極めて通過しにくいことが示された.

分婏後の授乳ラットに経口投与した場合, 乳汁 中放射能濃度は投与後 2 時間に最高值を示し減少 した。しかし, 血液中濃度と比較して, その濃度 比は0. 23〜0.72 と低く, 乳汁中への移行は小さい ことが明らかとなった。

${ }^{2} \mathrm{H}-\mathrm{CU}-83$ を $25 \mu \mathrm{g} / \mathrm{kg}$ で 1 日 1 回, 単回投与 と 7 日間あるいは14日間連続経口投与した時の血 液中濃度推移, 組織分布おょび尿, 粪中排泄を検 討した. 7 日めるいは14日間連続投与の最終投与 後の血液中濃度推移は単回投与の結果と差がなか った. 毎回投与後 24 時間の血液中濃度は投与後 5 


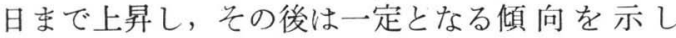
た. 組織内濃度は, 単回投与に比べ 7 日間投与で は増加が見られたが，7日間と14日間投与ではほ ぼ同じ濃度であった。交た，尿および粪中への放
射能の排泄は, 最終投与後 24 時間までにほぼ終了 した。 以上より, 本化合物の生体への蓄積性は極 めて低く，連続投与しても体内に残留しないと考 光られる。

\section{文献}

1）川辺良樹，稲葉裕美，高梨契典，水野敬和，星野英一，日野原好和：ラットの胃酸分 泌扤よび急性胃粘膜損傷に対する 15(R)-15-methylprostaglandin $\mathrm{E}_{2}$ (Arbaprostil) 拈よび 15(S)-15-methylprostaglandin $\mathrm{E}_{2}$ の作用. 薬理と治療, 16 (Suppl. 4)： $861-868$ (1988).

2）大澤康次，幡野 恵，西宮一尋，岡崎 彬，太田真一，宇田文昭，柳田由紀，檜垣洋 子, 吉田知江里：15(R)-15-Methylprostaglandin $\mathrm{E}_{2}$ のラットにおける生体内動態の 研究（第 1 報）血液中濃度, 排泄, 腸肝循環並びに蛋白結合. 薬理と治療, 16 (Suppl. 4) : 897-906 (1988).

3）大澤康次, 幡野 恵, 西宮一尋, 岡崎 彬, 太田真一, 宇田文昭, 柳田由紀, 檜垣洋 子, 吉田知江里 : 15(R)-15-Methylprostaglandin $\mathrm{E}_{2}$ のラットに物ける生体内動態の 研究 (第 2 報) 血液, 消化管, 尿並びに胆汁中代謝物. 薬理と治療, 16 (Suppl. 4)： 907-916 (1988).

4）西宮一蕁, 幡野 恵, 大澤康次, 岡崎 彬: 15(R)-15-Methylprostaglandin $\mathrm{E}_{2}{ }^{-}$のラ ットに拈ける生体内動態の研究（第 3 報）異性化並びに消化管吸収. 薬理と治療, 16 (Suppl. 4) : 917-924 (1988).

5) Wickrema, Sinha, A.J., Shaw, S.R. and Thornburgh, B.A. : Absorption, tissue distribution, and excretion of ${ }^{3} \mathrm{H}$-labeled arbaprostil in the male rat. $E . J$. Drug Metab. Pharmacokinet., $10: 171-177$ (1985).

6) Thornburgh, B.A., Shaw, S.R. and Wickrema, Sinha, A.J. : Isolation and characterization of urinary metabolites of arbaprostil in the rat. ibid., $11: 61-69$ (1986).

7）菅原和信, 豊口禎子：薬剂の母乳への移行, 南山堂（1984）. 